\title{
Related Problems of the Vocational Qualification Standard for Online Financial Marketing
}

\author{
Haijun Zhao \\ Senior Economist of the Guangdong Provincial E-Commerce Key \\ Laboratory of Guangdong University of Business Studies, and Secretary- \\ General of China Electronic Commerce Association Securities Information \\ Broadcast Committee
}

\begin{abstract}
The prosperity of the Chinese financial market and the development of financial information technology have given rise to a new occupation, "online financial marketing". However, in our higher education, no special course system for "online financial marketing" has been set up, and our vocational education also lacks a set of scientific vocational qualification standard for "online financial marketing". This paper attempts to solve this problem. On the basis of analyzing the scientific connotation, vocational category and social demand of "online financial marketing" and defining the principles for formulating the vocational qualification standard for "online financial marketing", this paper puts forward the basic framework of the vocational qualification standard for "online financial marketing".
\end{abstract}

\section{Introduction}

Online financial marketing is a compound phrase. To comprehensively understand the concept and disciplinary connotation of "online financial marketing", to clarify the objects of online financial marketing, and to fully understand the responsibilities of and qualifications for the occupation of online financial marketing, we must analyze the phrasal structure of "online financial marketing".

"Online financial marketing" is a phrase composed of three basic words, "online", "finance" and "marketing". As "online" and "finance" can form "online finance", and "finance" and "marketing" can form "financial marketing" "online" and "financial marketing" can form "online financial marketing", and "online finance" and "marketing" can form "online financial marketing" . Therefore, "online financial marketing" has two meanings, financial marketing with "online network" as the marketing tool and marketing with "online finance" as the marketing object. The former refers to the process of 
successfully introducing financial products and services to consumers by using online technologies to conduct online market survey, online promotion and publicity of traditional financial services; the latter refers to all-directional introduction and promotion activities specially for financial products and services based on online technologies. The marketing objects of the former include all the financial products and financial services, with their marketing method being "online marketing"; the marketing objects of the latter are high-tech financial products and services with modern online information technology as the means, including online banking, online securities, online fund, online futures and online insurance etc., with their marketing method including not only "online marketing" but also traditional marketing.

Therefore, the disciplinary studies of online financial marketing shall not only include financial marketing with "online network" as the marketing means, but also marketing with "online finance" as the marketing object. Both financial marketing with "online network" as the marketing means and marketing with "online finance" as the marketing object are basic categories of the studies on financial e-commerce. We can call the combination of the two the discipline of online financial marketing. That is to say, the discipline of online financial marketing is a special learning of online marketing of financial products and services and marketing of online finance. As to the disciplinary attributes, according to the Catalogue of Undergraduate Specialties of Regular Institution of Higher Education(Ministry of Education ,1998) [1], the discipline of online financial marketing is an inter-disciplinary science of finance (020104), marketing (110202) and information management and information system (110102). More accurately, it is an interdisciplinary subject of finance (020104) and e-commerce (110209 W), a specialty outside the catalogue approved by the Ministry of Education. We can say that it is an applied branch discipline of finance or an applied branch discipline of ecommerce.

\section{The Occupational Category of Online Financial Marketing}

Like the information industry, e-commerce is an industry that can be intersected with any industry in the national economy and form a new field in this industry. The intersection of e-commerce and finance forms a new field of financial e-commerce. The driving business of financial e-commerce is online financial marketing, which is the soul and foundation for financial e-commerce. Though there is classification of the occupation of online financial marketing in Classification and Dictionary of Occupations in the People's Republic of China [2] and national standard GB / T 6565-1999 Occupational Classification and Codes [3], in reality, online financial marketing has indeed become a new industry branch and a new occupation. In recent years, almost all the big securities companies, fund management companies, big commercial banks and insurance companies have set up an e-commerce department of online marketing department. In their recruitment announcements, the position of "online marketing" has the largest demand. Meanwhile, with the great development of financial informatization and cyberization, and online finance, online financial 
marketing will become a very important occupational position, and the cause of online financial marketing will provide the society with thousands of new occupational posts. The high-tech marketing measures of online financial marketing, while promoting the innovation and development of the financial cause, will also quickly create a new wealthy group because of its special speed of market opening and online proliferation effects. This wealth gathering effect, in turn, will further elevate the social status of online financial marketing talents and thereby accelerate the process of professionalization of online financial marketing.

\section{Occupational Demands of Online Financial Marketing}

\subsection{Social demand for the occupation of online financial marketing}

As a new marketing means in the financial industry and a new occupation in the field of e-commerce, online financial marketing has started to display its boundless charms. For example, the Agricultural Bank of China started the online fund direct sale service in April 2006 [4], thus becoming the first large-scale state-owned commercial bank to open online fund sales service. Seven companies participate in the online fund direct sale platform of the Agricultural Bank of China, Guotai Fund, Fuguo Fund, Changsheng Fund, Dacheng Fund, Changxin Fund, Penghua Fund and Zhonghai Fund. The varieties of participating funds include over 30 open-ended funds from money fund, guaranteed fund, bond fund, index fund and leverage fund to equity fund. By the end of last July, the number of new fund transaction customers via this system had surpassed 11 thousand. In the beginning of September, the Agricultural Bank of China also united with 7 fund companies to hold online fund direct sale demonstration meetings in Shanghai and Shenzhen etc. Selling funds online and staging road shows on the spot are typical and comprehensive online financing marketing operations.

From the above case, we can see two modes of online financial marketingpassive marketing and active marketing. To set up an online fund direct sale platform and develop online fund service are passive online financial marketing. To stage road shows of online fund service or to further conduct online road shows and to promote online fund service are active online financing marketing. What passive marketing needs are online financing talents versed in technology, that is, the talents for building and developing the online financial platform, while what active marketing, as the continuation and expansion of passive marketing, needs are financial marketing talents and online marketing talents versed in business. "Online finance" adds wings to financial business. Plus active marketing, "falconers" come into being, who will make modern financial business "soar as it likes above the global village". The total amount of financial business will also rapidly increase in the form of geometric growth. The rapid growth of modern financial business will inevitably bring about a large amount of demand for professionals in online financial marketing. 


\subsection{Demand of skills for the occupation of online financial marketing}

From the above analysis, we can see that online financial marketing talents are compound talents integrating multiple knowledge skills including financial business knowledge, online information technology, marketing skills and skills in using online tools. A qualified online financial marketing talent shall not only master the basic theories of finance and financial market, but also are familiar with all kinds of financial products, financial tools and financial services in the financial market, be able to not only conduct information resource planning of online financial marketing management and system platform construction, but also guarantee the financial security and information security of online financial services, not only grasp the basic theories and methods of marketing but also have practical ability in marketing, and not only be able to skillfully use all kinds of online tools to conduct marketing but also have the working ability to guide customers, cultivate customers and retain customers. The author has listed some basic qualities that a qualified online financial marketing talent shall have in the following table.

Table 1 Basic Skills that an Online Financial Marketing Talent Shall Command

\begin{tabular}{|c|c|c|c|c|}
\hline $\begin{array}{c}\text { Knowledge in } \\
\text { financial } \\
\text { business }\end{array}$ & $\begin{array}{c}\text { Online } \\
\text { information } \\
\text { technology }\end{array}$ & Marketing skills & $\begin{array}{l}\text { Use of online } \\
\text { tools }\end{array}$ & $\begin{array}{c}\text { Other } \\
\text { knowledge } \\
\text { and skills }\end{array}$ \\
\hline $\begin{array}{l}\text { Grasp the basic } \\
\text { knowledge of } \\
\text { finance and } \\
\text { financial market }\end{array}$ & $\begin{array}{l}\text { Have the basic } \\
\text { skills in } \\
\text { information } \\
\text { resource } \\
\text { planning, and } \\
\text { be able to } \\
\text { skillfully } \\
\text { conduct } \\
\text { information } \\
\text { resource } \\
\text { planning of } \\
\text { online financial } \\
\text { marketing } \\
\text { management }\end{array}$ & $\begin{array}{c}\text { Grasp the basic } \\
\text { theories and } \\
\text { methods of } \\
\text { marketing }\end{array}$ & $\begin{array}{l}\text { Be familiar with } \\
\text { and skillfully use } \\
\text { such common } \\
\text { online promotion } \\
\text { tools as google, } \\
\text { yahoo, sohu and } \\
\text { website title to } \\
\text { conduct website } \\
\text { and business } \\
\text { promotion }\end{array}$ & $\begin{array}{l}\text { Grasp the } \\
\text { basic } \\
\text { knowledge } \\
\text { of } \\
\text { consumpti } \\
\text { on } \\
\text { psycholog } \\
\text { y and } \\
\text { behavior } \\
\text { finance }\end{array}$ \\
\hline $\begin{array}{l}\text { Be familiar with } \\
\text { all kinds of } \\
\text { financial } \\
\text { products, } \\
\text { financial tools } \\
\text { and financial } \\
\text { services } \\
\text { including } \\
\text { banking } \\
\text { business, } \\
\text { monetary } \\
\text { market, capital } \\
\text { market, foreign } \\
\text { exchange } \\
\text { market, futures } \\
\text { market, derived } \\
\text { market, gold } \\
\text { market and } \\
\text { property right } \\
\text { market } \\
\end{array}$ & $\begin{array}{l}\text { Be familiar with } \\
\text { and can adeptly } \\
\text { use such } \\
\text { modern online } \\
\text { information and } \\
\text { communication } \\
\text { technologies as } \\
\text { the internet, } \\
\text { broadcasting } \\
\text { and TV } \\
\text { networks, } \\
\text { telecommunicat } \\
\text { ion network and } \\
\text { mobile } \\
\text { communication } \\
\text { network, and } \\
\text { construct online } \\
\text { marketing } \\
\text { platforms }\end{array}$ & $\begin{array}{c}\text { Have the basic } \\
\text { skills in market } \\
\text { survey, market } \\
\text { segmentation and } \\
\text { market } \\
\text { development, be } \\
\text { able to } \\
\text { independently } \\
\text { conduct analysis of } \\
\text { financial marketing } \\
\text { environment, } \\
\text { formulate financial } \\
\text { marketing } \\
\text { strategies, and } \\
\text { conduct financial } \\
\text { marketing } \\
\text { performance } \\
\text { evaluation and } \\
\text { regulation } \\
\text { management }\end{array}$ & $\begin{array}{c}\text { Be able to } \\
\text { skillfully use } \\
\text { multiple } \\
\text { information } \\
\text { channels such as } \\
\text { e-mail, e- } \\
\text { magazine, online } \\
\text { fax, short } \\
\text { message, WAP } \\
\text { web and blog to } \\
\text { conduct financial } \\
\text { marketing } \\
\text { activities }\end{array}$ & $\begin{array}{l}\text { Customer } \\
\text { training } \\
\text { skills for } \\
\text { transmittin } \\
\text { g financial } \\
\text { knowledge } \\
\text { and } \\
\text { guiding } \\
\text { financial } \\
\text { consumpti } \\
\text { on }\end{array}$ \\
\hline $\begin{array}{c}\text { Be familiar with } \\
\text { the basic } \\
\text { business } \\
\text { processes of } \\
\text { banking }\end{array}$ & $\begin{array}{l}\text { Be familiar with } \\
\text { the management } \\
\text { processes and } \\
\text { service } \\
\text { processes of }\end{array}$ & $\begin{array}{l}\text { Be familiar with } \\
\text { and grasp CRM } \\
\text { system, do well in } \\
\text { customer } \\
\text { management work }\end{array}$ & $\begin{array}{l}\text { Know the volume } \\
\text { of flow of large } \\
\text { portal websites, } \\
\text { selectively } \\
\text { publish online }\end{array}$ & $\begin{array}{l}\text { Basic } \\
\text { skills to } \\
\text { help } \\
\text { customers } \\
\text { to manage }\end{array}$ \\
\hline
\end{tabular}


100 Related Problems of the Vocational Qualification Standard for Online Financial

Marketing

\begin{tabular}{|c|c|c|c|c|}
\hline $\begin{array}{c}\text { business, } \\
\text { securities } \\
\text { business, fund } \\
\text { business, bond } \\
\text { business, futures } \\
\text { business and } \\
\text { insurance } \\
\text { business }\end{array}$ & $\begin{array}{c}\text { such online } \\
\text { finance as } \\
\text { online banking, } \\
\text { online } \\
\text { securities, } \\
\text { online fund, } \\
\text { online futures } \\
\text { and online } \\
\text { insurance }\end{array}$ & $\begin{array}{l}\text { and have basic } \\
\text { skills in database } \\
\text { marketing }\end{array}$ & $\begin{array}{l}\text { advertisements, } \\
\text { or have reciprocal } \\
\text { links, or join in } \\
\text { narrow ad league, } \\
\text { publish narrow } \\
\text { ads, or use } \\
\text { functional } \\
\text { software to } \\
\text { conduct pushing- } \\
\text { based marketing }\end{array}$ & $\begin{array}{c}\text { finance or } \\
\text { provide } \\
\text { customers } \\
\text { with } \\
\text { financial } \\
\text { manageme } \\
\text { nt } \\
\text { consultatio } \\
\text { n services }\end{array}$ \\
\hline $\begin{array}{l}\text { Understand } \\
\text { related financial } \\
\text { policies and } \\
\text { financial laws } \\
\text { and regulations }\end{array}$ & $\begin{array}{l}\text { Be familiar with } \\
\text { basic online } \\
\text { formation } \\
\text { security } \\
\text { technologies } \\
\text { and ensure the } \\
\text { information } \\
\text { security of } \\
\text { online financial } \\
\text { services }\end{array}$ & $\begin{array}{l}\text { Grasp such basic } \\
\text { marketing or } \\
\text { promotion } \\
\text { techniques as } \\
\text { advertisement } \\
\text { promotion, price } \\
\text { promotion, service } \\
\text { promotion and } \\
\text { channel promotion, } \\
\text { and have the } \\
\text { practical ability in } \\
\text { marketing }\end{array}$ & $\begin{array}{l}\text { Such publicity } \\
\text { reports as focus } \\
\text { media and digital } \\
\text { broadcasting }\end{array}$ & $\begin{array}{l}\text { Emotional } \\
\text { quotient to } \\
\text { maintain } \\
\text { close } \\
\text { relationshi } \\
\text { p with } \\
\text { customers }\end{array}$ \\
\hline
\end{tabular}

\section{The Urgency of Developing and Formulating the Vocational Standard for Online Financial Marketing}

The occupation of online financial marketing demands compound talents with both modern financial business ability and online marketing skills, and it is difficult to cultivate such talents and the cultivation cycle is relatively long. However, the reality is that almost no finance specialty, marketing specialty or e-commerce specialty in each institution of higher education across China has set up the course of "online financial marketing"; whereas the present situation is that the online financial marketing industry has emerged and displayed the tendency for rapid development. Currently every financial institution develops online financial services. The lack of online financial marketing talents has become the bottleneck for the development of the modern financial service industry. There have been frequent reports in the media about the fact that large-scale financial institutions fail to recruit suitable online financial service talents. Therefore short-term vocational skill training becomes an inevitable solution.

In order to ensure the quality of the vocational training of online financial marketing and cultivate qualified practical talents, it is particularly urgent to develop a set of scientific and reasonable "vocational qualification standard system for online financial marketing". This shall arouse sufficient attention of related experts, scholars, the state administrative departments of the finance industry, in particular, the financial e-commerce industry, and related industry associations. 


\section{The Basic Framework of the Vocational Standard for Online Financial Marketing}

Vocational qualification standard is standardized requirements on the working ability and level of practitioners on the basis of occupational classification and the activity contents of an occupation (type of work). Vocational qualification standard occupies the most important position in the whole national vocational qualification system and plays a guiding role. It will directly guide the direction and contents of vocational education and skill training and the key points and rules for conducting evaluation and assessment of students. It plays a vital role in the human resource development strategies of the national economy. The vocational qualification standard system must be a measurement system of uniform knowledge and skills with common characteristics of an industry that not only meets the objectives of the labor market and enterprise development but also meets the actual needs of modern economic development. It is the necessary foundation for the establishment of a national vocational qualification certificate system. Online financial marketing, as a new occupation born under the conditions of modern online information technology, must have its own set of qualification standard system if it is to be included into the uniform national vocational qualification certificate system.

The principles for formulating the vocational standard for online financial marketing shall accord with the general principles of national vocational standard compilation: with occupational activities as the orientation, occupational skills as the core. With occupational activities as the orientation is to plan the boundary and content scope of necessary knowledge and skills of practitioners of an occupation with the occupational behavior characteristics, behavior contents and general behavior patterns of online financial marketing as the main thread; with occupational skills as the core is to study out the levels of practitioners of the occupation and their corresponding skills and operation abilities with the occupational technical characteristics, technical contents, technical grades and application ability demands as the review targets.

According to the above principles and following Technical Regulations on Formulating National Vocational Standard [5], the following basic framework is proposed for the vocational qualification standard for online financial marketing:

(1) Title of the occupation

"Online financial marketer" is used for professionals engaged in the occupation of online financial marketing

(2) Definition of the occupation

An online financial marketing master is a compound business talent who has received uniform training from an authoritative training system and passed the assessment and evaluation, can use online information technology to conduct financial business publicity and service promotion, and can conduct online sales and management activities of financial products and services including e-finance or online finance, and a professional engaged in operation and management who commands comprehensive financial knowledge and operation and management ideas, operation methods and realization measures of financial e-commerce and can 
provide informatization and cyberization business services or management services for a certain link or the whole of a financial institution.

(3)Occupation levels and basic standards

Online financial marketers have three levels, with their titles and standards being respectively:

1) Online financial marketing member: have general basic financial knowledge, be able to use basic online marketing tools and independently complete the publicity and service promotion of financial business and the online marketing of financial products and services including e-finance or online finance.

2) Online financial marketing master: have solid financial theoretical basis, be able to take an overall view of the situation of financial market and the development direction of online information technology, be familiar with online finance technology, be able to develop the information resource planning and system construction of online financial marketing, be able to skillfully use modern online marketing tools to conduct financial marketing, be able to solve the general technical difficult problems in online financial marketing and difficult problems of customer services, and be able to guide and train online financial marketing members.

3) Senior online financial marketing master: have profound financial theoretical knowledge, command the financial innovation forefront and the development forefront of online information technology, be versed in online financial technology, be able to lead the information resource planning of an financial institution and the system development and platform construction of online financial services, be able to develop and formulate online financial marketing strategies and conduct the master planning and coordination of online financial marketing, be able for smoothly solve the technical difficult problems in online financial marketing and difficult problems of customer services, be able to smoothly use cutting edge online information technology in the practice of online financial marketing and conduct financial project innovation, and be able to conduct systematic technical training on online financial marketing.

(4)Requirements for registration for an examination:

1) Online financial marketing member: students registering themselves for this level of examination must have a degree of junior college.

2) Online financial marketing master: students registering themselves for this level of examination must have a bachelor' s degree or have a degree of junior college and have worked in a related post for over 1 year, or have obtained the vocational qualification certificate for an online financial marketing member

3) Senior online financial marketing master: students registering themselves for this level of examination must have a master' $s$ degree or have a bachelor' $s$ degree and have worked in a related post for over 1 year, or have a degree of junior college and have worked in a related post for over 3 years, or have obtained the vocational qualification certificate for an online financial marketing master.

(5)Training requirements

People registered for examinations shall participate in the special training held by a local training institution recognized by the online financial marketer certification administration authority and complete the whole course of training according to regulations. The contents and methods of training include: lessons 
(lectures and case discussions), exercise (homework and experiments), practical operation (practices and papers) and commercial salons etc.

1) Training term

Online financial marketing member: the training takes about 1-2 months (120 class hours), including about 36 class hours of lectures and abut 84 class hours of exercise and practical operation (completed by students with self discipline).

Online financial marketing master: the training takes about 1-2 months (120 class hours), including about 60 class hours of lectures and case discussions and abut 60 class hours of exercise and practical operation (completed by students with self discipline).

Senior online financial marketing master: the training takes about 2-4 months (240 class hours), including about 100 class hours of lectures, case discussions and commercial salons and abut 140 class hours of practices and project design (completed by students with self discipline).

2) Training teachers

A special teacher team selected, trained and determined by the online financial marketer certification administration authority according to the general requirements of the vocational training objectives of online financial marketing.

3) Equipment for training places

Audio-visual classrooms, e-commerce applied experiment platforms, online financial service experiment platforms and online examination systems that meet the standards stipulated by the educational department.

(6) Appraisal requirements

To acquire a vocational qualification certificate for online financial marketing, one must pass the examination and appraisal of the online financial marketer certification administration authority or its authorized organization. Senior online financial marketing masters, online financial marketing masters and online financial marketing members must pass online written examination. Besides, senior online financial marketing masers shall complete a stipulated project design and oral defense for their paper and online financial marketing masters shall also complete stipulated paper for the specialty.

1) Online financial marketing member

Those who have one of the following qualifications can acquire a vocational qualification certificate for an online financial marketing member: (1) be registered for and pass the systematic training of the online financial marketer certification administration authority or its authorized organization, and acquire a course completion certificate for an online financial marketing member; (2) have a bachelor's degree and have worked in a post of online financial marketing for over 1 year or have a degree of junior college and have worked in a post of online financial marketing for over 2 years, and file an application with the online financial marketer certification administration authority or its authorized organization for a certificate of an online financial marketing member and pass the examination.

2) Online financial marketing master

Those who have one of the following qualifications can acquire a vocational qualification certificate for an online financial marketing master: (1) be registered for and pass the systematic training of the online financial marketer certification administration authority or its authorized organization, and acquire a course 
completion certificate for an online financial marketing master; (2) have acquired a vocational qualification certificate for an online financial marketing member and have worked in the post of the occupation for over 2 years, and file an application with the online financial marketer certification administration authority or its authorized organization for the certificate of an online financial marketing master and pass the examination; (3) have a bachelor's degree and have worked in a post of online financial marketing for over 2 year or have a master's degree and have worked in a post of online financial marketing for over 1 years, and file an application with the online financial marketer certification administration authority or its authorized organization for a certificate of an online financial marketing master and pass the examination.

3) Senior online financial marketing master

Those who have one of the following qualifications can acquire a vocational qualification certificate for a senior online financial marketing master: (1) be registered for and pass the systematic training of the online financial marketer certification administration authority or its authorized organization, and acquire a course completion certificate for a senior online financial marketing master; (2) have acquired a vocational qualification certificate for an online financial marketing master and have worked in the post of the occupation for over 3 years, and file an application with the online financial marketer certification administration authority or its authorized organization for the certificate of a senior online financial marketing master and pass the examination; (3) have a master's degree and have worked in a post of online financial marketing for over 3 years, and file an application with the online financial marketer certification administration authority or its authorized organization for a certificate of a senior online financial marketing master and pass the examination.

(7)The proportion table for vocational skill examination

Table 2 The Proportion Table for the Examination of Knowledge and Skills of the Online Financial Marketing Occupation

\begin{tabular}{|c|c|c|c|c|c|}
\hline $\begin{array}{l}\text { Online financial } \\
\text { marketing } \\
\text { knowledge module }\end{array}$ & Level & $\begin{array}{l}\text { Prop- } \\
\text { ortion }\end{array}$ & $\begin{array}{l}\text { Online financial } \\
\text { marketing skill } \\
\text { module }\end{array}$ & Level & $\begin{array}{l}\text { Prop } \\
- \\
\text { ortio } \\
\mathrm{n}\end{array}$ \\
\hline $\begin{array}{l}\text { Basic knowledge of } \\
\text { finance }\end{array}$ & $\begin{array}{l}\text { Necessary for } \\
\text { online } \\
\text { financial } \\
\text { marketing } \\
\text { members }\end{array}$ & $1 / 6$ & $\begin{array}{l}\text { Successful } \\
\text { employment of } \\
\text { ordinary online } \\
\text { marketing tools }\end{array}$ & $\begin{array}{l}\text { Necessary for } \\
\text { online financial } \\
\text { marketing } \\
\text { members }\end{array}$ & $1 / 2$ \\
\hline $\begin{array}{l}\text { Financial market, } \\
\text { financial products, } \\
\text { financial tools and } \\
\text { financial services }\end{array}$ & $\begin{array}{l}\text { Necessary for } \\
\text { online } \\
\text { financial } \\
\text { marketing } \\
\text { masters }\end{array}$ & $1 / 6$ & $\begin{array}{l}\text { Flexible } \\
\text { employment of } \\
\text { advanced online } \\
\text { marketing tools }\end{array}$ & $\begin{array}{l}\text { Necessary for } \\
\text { online financial } \\
\text { marketing } \\
\text { masters }\end{array}$ & $1 / 3$ \\
\hline $\begin{array}{l}\text { Financial projects } \\
\text { and financial } \\
\text { innovation }\end{array}$ & $\begin{array}{l}\text { Necessary for } \\
\text { senior online } \\
\text { financial } \\
\text { marketing } \\
\text { masters }\end{array}$ & $1 / 6$ & $\begin{array}{l}\text { The information } \\
\text { resource } \\
\text { planning and } \\
\text { system design of } \\
\text { online financial } \\
\text { marketing }\end{array}$ & $\begin{array}{l}\text { Necessary for } \\
\text { online financial } \\
\text { marketing } \\
\text { masters }\end{array}$ & $1 / 6$ \\
\hline $\begin{array}{l}\text { Basic knowledge of } \\
\text { online information }\end{array}$ & $\begin{array}{l}\text { Necessary for } \\
\text { online }\end{array}$ & $1 / 6$ & $\begin{array}{l}\text { Information } \\
\text { resource }\end{array}$ & $\begin{array}{l}\text { Necessary for } \\
\text { senior online }\end{array}$ & $1 / 6$ \\
\hline
\end{tabular}




\begin{tabular}{|c|c|c|c|c|c|}
\hline and e-commerce & $\begin{array}{l}\text { financial } \\
\text { marketing } \\
\text { members }\end{array}$ & & $\begin{array}{l}\text { planning of } \\
\text { online financial } \\
\text { marketing and } \\
\text { the project } \\
\text { management of } \\
\text { online } \\
\text { marketing } \\
\text { platform } \\
\text { development }\end{array}$ & $\begin{array}{l}\text { financial } \\
\text { marketing } \\
\text { masters }\end{array}$ & \\
\hline $\begin{array}{l}\text { Theories of online } \\
\text { economy } \\
\text { financial } \\
\text { commerce }\end{array}$ & $\begin{array}{l}\text { Necessary for } \\
\text { online } \\
\text { financial } \\
\text { marketing } \\
\text { masters and } \\
\text { senior online } \\
\text { financial } \\
\text { marketing } \\
\text { masters }\end{array}$ & $\begin{array}{l}\text { Online } \\
\text { financial } \\
\text { marketin } \\
\mathrm{g} \\
\text { masters } \\
1 / 6 ; \\
\text { senior } \\
\text { online } \\
\text { financial } \\
\text { marketin } \\
\mathrm{g} \\
\text { masters } \\
1 / 6\end{array}$ & $\begin{array}{l}\text { The monitoring } \\
\text { and control of } \\
\text { online security }\end{array}$ & $\begin{array}{l}\text { Necessary for } \\
\text { senior online } \\
\text { financial } \\
\text { marketing } \\
\text { masters }\end{array}$ & $1 / 6$ \\
\hline $\begin{array}{l}\text { Laws } \\
\text { regulations, and } \\
\text { honesty } \\
\text { integrity, and moral } \\
\text { codes }\end{array}$ & $\begin{array}{l}\text { Necessary for } \\
\text { all the levels } \\
\text { of online } \\
\text { financial } \\
\text { marketing } \\
\text { talents }\end{array}$ & $1 / 6$ & $\begin{array}{l}\text { Diagnosis and } \\
\text { repair } \\
\text { technical of } \\
\text { failures in the } \\
\text { online } \\
\text { marketing } \\
\text { system }\end{array}$ & $\begin{array}{l}\text { Necessary for } \\
\text { senior online } \\
\text { financial } \\
\text { marketing } \\
\text { masters }\end{array}$ & $1 / 6$ \\
\hline
\end{tabular}

Note: The proportions in the table reflect the proportions of each type of knowledge and work content or the related knowledge of occupational functions in training and examination

\section{The Association Strategies for the Formulation of Vocational Standard for Online Financial Marketing}

The above basic framework is a sketchy conception intending to start further discussion. The study and formulation of a vocational standard shall not stop at the attention of a scholar from the academic perspective. People of this occupation, the business organizations of this occupation and their administrative departments shall pay more attention to it from the perspective related with their own interests, the interests of the units and industry administration. The state labor and social security department shall perform its administrative duties according to related administrative laws and regulations, operate from a strategically advantageous position, and pay attention to it from the perspective of standardizing the vocational training market. In fact, it is basically industry associations that preside over the study, formulation, issuing and implementation of overseas standards and international standards. For example, the internationally current "Chartered Financial Analyst (CFA)" certificate and training and certification standard was designed and developed by the Association for Investment Management and Research (AIMR), The International Commercial Art Designer (ICAD) certificate and training and certification standard was designed and developed by the International Commercial Art Designer Association (ICADA), etc.

In our country, due to the remaining influence of the planned system, related laws and regulations proclaim that "the labor and personnel administration departments of 
the State Council shall, together with the related departments in charge of an industry, study and formulate the scope of vocational qualifications, occupational (specialty and type of work) classification, vocational qualification standard and the measures for degree authentication, qualifying examination, expert assessment and skill appraisal." The related industry associations are excluded from the power of studying and formulating vocational qualification standards, so much so that Classification of Occupations in the People's Republic of China also has such a stipulation: the title and definition of a new occupation shall be determined by the Ministry of Labor and Social Security after the demonstration of experts. Under the present new technology and competition conditions, in particular, after our country's accession to the WTO, new industries, new trades and new occupations are emerging. If the title and definition of a new occupation is determined by the Ministry of Labor and Social Security, it will affect and lag behind the development and social demand of new occupations. It is a historical necessity for related industry associations to assume the duties and responsibilities for developing and formulating the standards for new occupations, which also accords with the big direction of the reform of government administrative systems. In this respect, the China Electronic Commerce Association has taken the lead and made a good initiative. It formally published "Certification Standard for Chinese Electronic Commerce Professional Managers (trial implementation)" in the form of No. 1 document of CCCEM[2005] in May 2005, which has exerted wide influence in the society. At the same time, the association has cultivated a large number of qualified Chinese electronic commerce professional managers for the construction of the national economy. Such a measure shall also be adopted for the development and formulation of the vocational standard for online financial marketing so as to make the new occupation of online financial marketers serve the development of our national economy rightfully and with high quality as soon as possible.

\section{References}

1. "Ministry of Education of china: Catalogue of Undergraduate Specialties of Regular Institution of Higher Education (1998)" . http://jwc.qfnu.edu.cn/Article/wxfg/jywx/199803/19980329113934.htm

2. Working Committee of the State Occupational Classification and Vocational Qualifications: Classification and Dictionary of Occupations in the People's Republic of China, China Labor \& Social Security Publishing House, Beijing,May (1995)

3. State Bureau of People's Republic of China for Quality and Technical Supervision: Occupational Classification and Codes-State standard GB / T 65651999, (March 1, 1999)

4. Tao Li, "The Agricultural Bank of China Launches Online Fund Direct Sale", China Business Times, (September 10, 2006)

5. "Ministry of Labor and Social Security of the People' s Republic of China", Technical Regulations on Formulating National Vocational Standard, (July 2001). 